\title{
Longitudinal distribution of Chironomidae (Diptera) downstream from a dam in a neotropical river
}

\author{
Pinha ${ }^{a}$, GD., Aviz ${ }^{b}$, D., Lopes Filho ${ }^{a}$, DR., Petsch ${ }^{a}$, DK., Marchese ${ }^{c}$, MR. and Takeda ${ }^{d}, A M$. \\ ${ }^{a}$ Programa de Pós-Graduação em Ecologia de Ambientes Aquáticos Continentais, Universidade Estadual de Maringá, \\ Av. Colombo 5790, CEP 87020-900, Maringá, PR, Brazil \\ ${ }^{b}$ Programa de Pós-Graduação em Ecologia Aquática e Pesca, Universidade Federal do Pará, Avenida Augusto Corrêa \\ s/n, Guamá, CEP 66650-000, Belém, PR, Brazil \\ 'Instituto Nacional de Limnologia - INALI/CONICET/UNL, José Maciá 1933, 3016, Santo Tomé, Santa Fé, Argentina \\ ${ }^{d}$ Universidade Estadual de Maringá - DBI/ NUPELIA/PEA, Av. Colombo 5790, CEP 87020-900, Maringá, PR, Brazil \\ *e-mail: gipinha@yahoo.com.br
}

Received June 13, 2012 - Accepted August 29, 2012 - Distributed August 31, 2013

(With 5 figures)

\begin{abstract}
The damming of a river causes dangerous consequences on structure of the environment downstream of the dam, modifying the sediment composition, which impose major adjustments in longitudinal distribution of benthic community. The construction of Engenheiro Sérgio Motta Dam in the Upper Paraná River has caused impacts on the aquatic communities, which are not yet fully known. This work aimed to provide more information about the effects of this impoundment on the structure of Chironomidae larvae assemblage. The analysis of data of physical and chemical variables in relation to biological data of 8 longitudinal sections in the Upper Paraná River showed that composition of Chironomidae larvae of stations near Engenheiro Sérgio Motta Dam differed of the other stations (farther of the Dam). The predominance of coarse sediments at stations upstream and finer sediments further downstream affected the choice of habitat by different morphotypes of Chironomidae and it caused a change in the structure of this assemblage in the longitudinal stretch.
\end{abstract}

Keywords: Diptera larvae, Neotropical region, substrata, hydroelectric power plant, upper Paraná River.

\section{Distribuição longitudinal de Chironomidae (Diptera) abaixo de uma barragem em um rio neotropical}

\section{Resumo}

O barramento de um rio pode causar graves consequências sobre a natureza do ambiente, abaixo da barragem, modificando a composição do sedimento, as quais impõem importantes ajustes da distribuição longitudinal das comunidades bentônicas. A construção da Usina Hidrelétrica Engenheiro Sérgio Motta no alto rio Paraná, tem causado impactos em várias comunidades aquáticas, que ainda não são totalmente conhecidos. Este trabalho objetivou fornecer mais informações sobre os efeitos desse represamento na assembleia de Chironomidae. A análise das variáveis físicas e químicas em relação aos dados biológicos de oito transectos longitudinais no alto rio Paraná revelou que a composição das larvas de Chironomidae das estações mais próximas à barragem da Usina Engenheiro Sérgio Motta diferiu das demais (estações mais distantes). A predominância de sedimentos mais grosseiros nas estações a montante e sedimentos mais finos mais a jusante afetou a escolha de habitat pelos diferentes morfotipos de Chironomidae, que levou a alteração na estrutura desta assembleia ao longo do trecho amostrado.

Palavras-chave: larvas de Diptera, região Neotropical, substrato, hidrelétrica, rio Paraná.

\section{Introduction}

Hydro-morphological features of rivers reflect longterm climatic and geomorphological processes which are influenced by global changes (Syrovátka et al., 2009) and, by anthropogenic impacts such as mining, dam construction, artificial eutrophication, river canalization and recreation (Dudgeon, 1994).
More information on the effects of impoundment to identify adverse impacts on the aquatic environment becomes necessary due to the increase of regulation of rivers flows worldwide (Petts, 1989; Dynesius and Nilsson, 1994). The knowledge of distribution patterns of river biota and habitat preferences is fundamental to effective assessment of possible effects of anthropogenic impacts on fluvial ecosystems. 
Dams modify the regional hydrological characteristics, limnological, climatological and biological functionality of the river, imposing major adjustments in the distribution of biotic communities (Matsumura-Tundisi, 1999). Damming impacts can promotes an accentuated decline in aquatic biodiversity, in function of destabilization of chemical and physical environment and modifications in dynamic and structure of biological communities.

The Paraná basin in Brazil is the most intensively exploited with the largest number of reservoirs among the large basins of South America as Engenheiro Souza Dias Dam (Jupiá), Engenheiro Sérgio Motta Dam (Porto Primavera) and Itaipu Dam (Souza Filho and Stevaux, 2004). The construction of the Engenheiro Sérgio Motta Dam at upstream of alluvial plain of Paraná River causes several changes on hydro-morphological dynamic of the river (Souza Filho et al., 2004). Many aquatic communities are affected as periphyton (Murakami et al., 2009), phytoplankton (Rodrigues et al., 2009), fish (Gubiani et al., 2007; Abujanra et al., 2009) and benthic invertebrates (Behrend et al., 2009; Rosin et al., 2009).

Chironomidae larvae are an important component of aquatic communities, both in density as well as in diversity (Armitage et al., 1995; Epler, 2001). Through of these larvae it is possible to obtain register of ecological process resulting from alterations occasioned by hydrologic variations (Moulton, 1998). Also, species composi- tion of Chironomidae assemblages differs qualitatively and quantitatively among microhabitats and larvae are highly selective in the choice of a habitat (Maasri et al., 2008).

The objective of the work was to answer to two questions: 1) how Engenheiro Sérgio Motta Dam influences on Chironomidae larvae along the main channel of Upper Paraná River and 2) how structure of larvae assemblage changes in a stretch of $85 \mathrm{~km}$. The hypothesis was that impoundment causes alterations in riverbed, consequently structure of Chironomidae assemblage differ from the dam to downstream sections.

\section{Material and Methods}

\subsection{Study area}

The Upper Paraná River is characterized by the presence of an extensive floodplain with about $230 \mathrm{~km}$ long, located $18 \mathrm{~km}$ downstream of the dam Engineer Sergio Motta (Porto Primavera) and approximately $200 \mathrm{~km}$ from the reservoir Itaipu (Orfeo and Stevaux, 2002).

The Hydroelectric Engenheiro Sérgio Motta is the largest of region, located in the Paraná River, $28 \mathrm{~km}$ upstream of the confluence with the Paranapanema.

Samples were taken at eight stations (S) downstream of Engenheiro Sérgio Motta Dam (Figure 1): S1 (6 km), $\mathrm{S} 2(10 \mathrm{~km}), \mathrm{S} 3(27 \mathrm{~km}), \mathrm{S} 4(37 \mathrm{~km}), \mathrm{S} 5(53 \mathrm{~km}), \mathrm{S} 6$ $(58 \mathrm{~km}), \mathrm{S} 7(74 \mathrm{~km})$ and $\mathrm{S} 8(81 \mathrm{~km})$. In the studied sec-

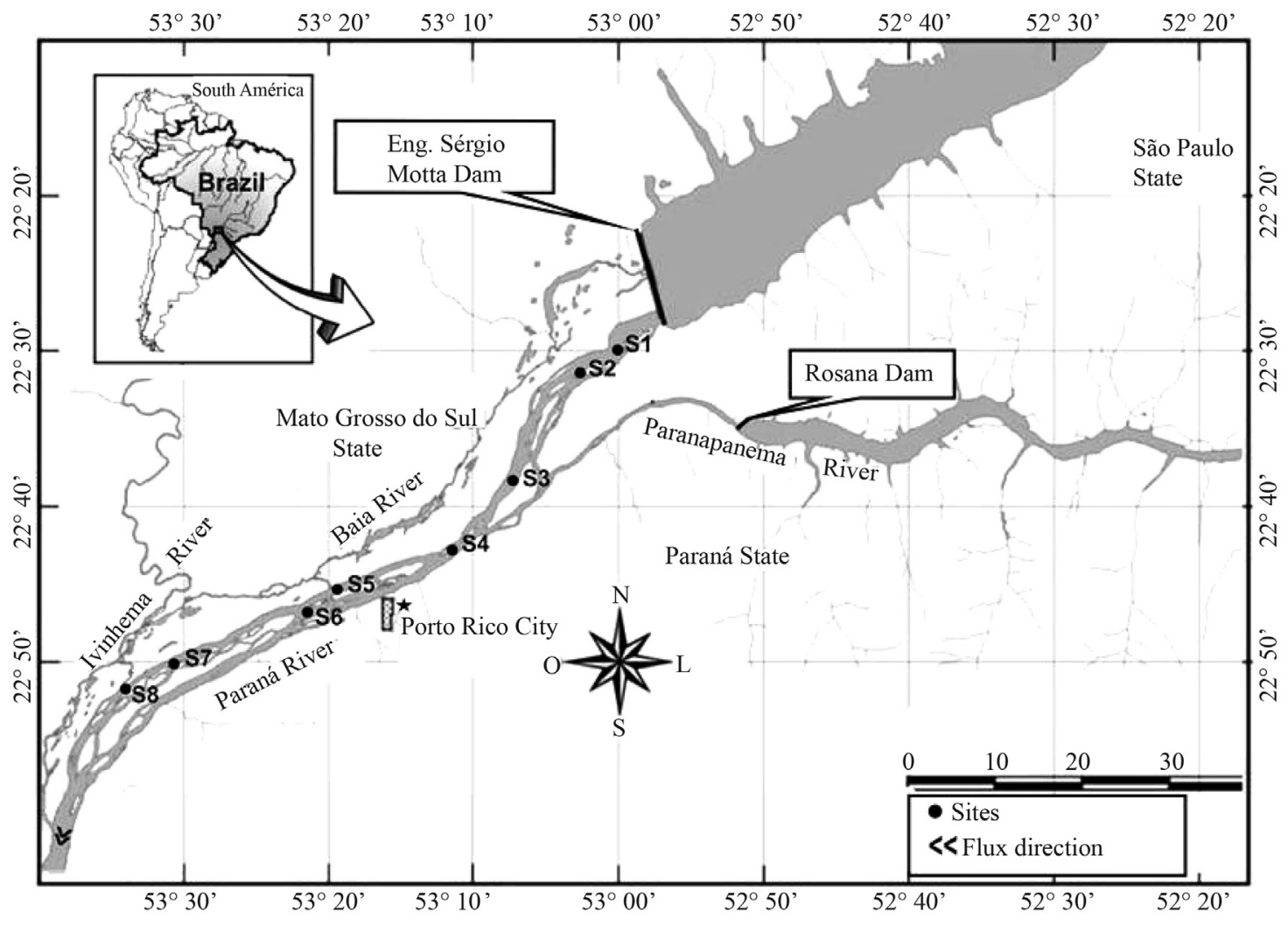

Figure 1 - Sampling stations in the Upper Paraná River. 
tion, the Paraná River shows a large anastomosed channel, low slope $\left(0.09 \mathrm{~m} . \mathrm{km}^{-1}\right)$, and with an extensive floodplain in the right bank.

\subsection{Sampling and laboratory procedures}

Sediment samples were collected on January, 2012, using a modified Petersen grab $\left(0.0345 \mathrm{~m}^{2}\right)$ along eight transects in longitudinal section of the Paraná River (Figure 1). In each transect, four sediment samples were taken at right and left banks (RB and LB) and in the center of river channel (C), three for biological analysis and one for grain size analysis.

To evaluate the influence of physical and chemical factors of the surface water on bottom fauna values of water conductivity $\left(\mu \mathrm{S} . \mathrm{cm}^{-1}\right), \mathrm{pH}$, turbidity (NTU), depth, temperature $\left({ }^{\circ} \mathrm{C}\right)$ and dissolved oxygen $\left(\mathrm{mg} \cdot \mathrm{L}^{-1}\right)$ were measured at same sites of sediment sampling. Granulometric texture was determined using methodology modified of Wentworth (1922). Organic matter content was obtained from by burning $10 \mathrm{~g}$ sediment at furnace $\left(560^{\circ} \mathrm{C}\right)$ during four hours.

Samplings for biological analysis were washed through a series of sieves (mesh size from 2.0 to $0.2 \mathrm{~mm}$ ). All organisms retained on 2.0 and $1.0 \mathrm{~mm}$ sieves were immediately picked out. The material retained on the $0.2 \mathrm{~mm}$ sieve was fixed in $80 \%$ alcohol and sorted under a stereoscopic microscope. All the invertebrates were identified and counted. Because Limnoperna fortunei (Dunker, 1857) be considered an ecosystem engineer (Darrigran and Damborenea, 2011) by altering habitat structure (Darrigran et al., 1998), data of presence and absence of this specie were used as a physical variable, which may influence the distribution of Chironomidae larvae.

Chironomidae larvae were dissected and mounted in slides with Hoyer, according to methodology described by Trivinho-Strixino (2011). The larvae were identified to the lowest possible taxonomic level using the identification keys of Trivinho-Strixino (2011) and Epler (2001). The slides are stored in the Zoobentos laboratory (NUPELIA/UEM), Maringá, Paraná, Brazil.

\subsection{Statistical analysis}

Chironomidae abundances were transformed to density (number of individuals $* 0.0345 \mathrm{~m}^{-2}$ ). Relative abundance of each taxon in stations was calculated, using the Statistica software (version 7.1). To characterize the Chironomidae assemblage in each site, Richness (S), Shannon-Wiener diversity index (Pielou, 1975); Pielou index (Pielou, 1966), and Kownacki's dominance index (Kownacki, 1971) were calculated.

Two-way analysis of variance (ANOVA) was used to compare the mean values of assemblage descriptors between transects and sites on the river channel. Prior to ANOVA, the normality of the data distribution (Kolmogorov-Smirnov test) and homoscedasticity of the variances (Shapiro-Wilk test) were tested.
In order to summarize the relation between the Chironomidae assemblages with the water physical and chemical data, a Canonical Correspondence Analysis (CCA) was performed (program MVSP 3.13). Biological data were fourth-root transformed, and environmental data were standardized and transformed. Prior to the CCA, the Draftsman plot routine was used to identify potential collinearity among environmental variables, excluding those that were strongly correlated $(r \geq 0.8)$ (program PRIMER ${ }^{\circledR}$ 6.0). The data of presence and absence of Limnoperna fortunei were used in the analysis of CCA as abiotic data.

\section{Results}

\subsection{Abiotic variables}

During the study, hydrological level of Paraná River was high (between 4.16 and $4.86 \mathrm{~m}$ ), a typical flood period. Table 1 shows values of water abiotic variables. A slight increase on $\mathrm{pH}$ was observed along the stretch of the river, the other variables did not show a spatial pattern.

All sites showed low organic matter content except in right banks of S1, S2 and center of S7 (Figure 2A). The bed of Paraná River was composed predominantly sandy (Figure 2B), with coarser fractions in sites S1 and S2.

\subsection{Biotic variables}

A total of 857 Chironomidae larvae were registered with 36 morphotypes, from three subfamilies - Chironominae (28 morphotypes), Tanypodinae (4 morphotypes) and Orthocladiinae (4 morphotypes).

The highest values of density of larvae were recorded at sites S1 (C) and S4 (LB) and lower density were found in majority at central regions (Figure 3A). The highest values of richness and diversity were observed in the banks of S4 and S6 (Figure 3B and Figure 3C) and evenness did not vary between stations (Figure 3D).

ANOVA confirmed significant differences in the descriptors between stations but not between sites (Table 2).

Riethia sp. 1 and Cricotopus sp.1 were abundant in the upstream sites (S1 to S3), while Lopescladius sp.1 was more frequent in stations of downstream (S4 to S6) (Figure 4).

Riethia sp.1 and Cricotopus sp.1 were dominant in upstream sites, while Lopescladius sp.1 was dominant in almost all stations, exception in S1. Saetheria sp.1 Tanytarsus type d and Djamabatista sp.2 dominated only in S4 (Table 3).

No significant variation on water abiotic data along of channel was recorded and the values were excluded from CCA analyses. Axes 1 and 2 of CCA were retained for interpretation $(p<0.05)$. The two first axes of CCA explained $34.72 \%$ of total data variability (axis $1=21.03 \%$ and axis $2=13.69 \%$ ). The first axis separated samples from stations S1 and S2 from other sites (Figure 5). The shaped group was due high contribution of 
Table 1 - Mean values and standard deviations (S.D.) of water physical and chemical of the stations. $\mathrm{T}=$ water temperature $\left({ }^{\circ} \mathrm{C}\right) ; \mathrm{COND}=$ water conductivity $\left(\mu \mathrm{S} . \mathrm{cm}^{-1}\right) ; \mathrm{DO}=$ dissolved oxygen $\left(\mathrm{mg} \cdot \mathrm{L}^{-1}\right) ; \mathrm{TURB}=$ water turbidity $(\mathrm{NTU}) ; \mathrm{VEL}=$ water velocity $\left(\mathrm{m} \cdot \mathrm{s}^{-1}\right)$.

\begin{tabular}{llccccccc}
\hline Stations & & $\mathbf{T}$ & $\mathbf{p H}$ & $\mathbf{C O N D}$ & $\mathbf{D O}$ & Depth & TURB & VEL \\
\hline S1 & Mean & 28.03 & 6.09 & 59.6 & 5.34 & 2.96 & 0.02 & 0.32 \\
& S.D. & $( \pm 0.40)$ & $( \pm 0.03)$ & $( \pm 1.65)$ & $( \pm 0.52)$ & $( \pm 0.54)$ & $( \pm 0.00)$ & $( \pm 0.21)$ \\
\hline S2 & Mean & 28.1 & 6.09 & 60.3 & 5.05 & 3.4 & 0.02 & 0.29 \\
& S.D. & $( \pm 0.30)$ & $( \pm 0.07)$ & $( \pm 0.92)$ & $( \pm 0.39)$ & $( \pm 0.38)$ & $( \pm 0.00)$ & $( \pm 0.18)$ \\
\hline S3 & Mean & 27.87 & 6.63 & 59.27 & 4.9 & 6.12 & 1.28 & 0.42 \\
& S.D. & $( \pm 0.38)$ & $( \pm 0.13)$ & $( \pm 1.66)$ & $( \pm 0.05)$ & $( \pm 2.26)$ & $( \pm 1.09)$ & $( \pm 0.04)$ \\
\hline S4 & Mean & 28.63 & 5.87 & 59.07 & 4.87 & 4.17 & 0.02 & 0.36 \\
& S.D. & $( \pm 0.57)$ & $( \pm 0.06)$ & $( \pm 0.47)$ & $( \pm 0.14)$ & $( \pm 2.38)$ & $( \pm 0.00)$ & $( \pm 0.31)$ \\
\hline S5 & Mean & 28.1 & 6.38 & 57.1 & 5.28 & 4.04 & 0.08 & 0.35 \\
& S.D. & $( \pm 0.30)$ & $( \pm 0.17)$ & $( \pm 1.47)$ & $( \pm 0.67)$ & $( \pm 1.54)$ & $( \pm 0.10)$ & $( \pm 0.15)$ \\
\hline S6 & Mean & 28.1 & 6.63 & 57.6 & 5.12 & 3.76 & 0.02 & 0.38 \\
& S.D. & $( \pm 0.30)$ & $( \pm 0.07)$ & $( \pm 2.02)$ & $( \pm 0.90)$ & $( \pm 1.18)$ & $( \pm 0.00)$ & $( \pm 0.19)$ \\
\hline S7 & Mean & 28.27 & 6.99 & 58.6 & 5.15 & 4.69 & 0.02 & 0.3 \\
& S.D. & $( \pm 0.32)$ & $( \pm 0.15)$ & $( \pm 1.76)$ & $( \pm 0.41)$ & $( \pm 2.14)$ & $( \pm 0.00)$ & $( \pm 0.18)$ \\
\hline S8 & Mean & 28.67 & 7.27 & 58.33 & 5.00 & 7.69 & 0.02 & 0.33 \\
& S.D. & $( \pm 0.29)$ & $( \pm 0.11)$ & $(1.58)$ & $( \pm 0.35)$ & $( \pm 1.47)$ & $( \pm 0.00)$ & $( \pm 0.17)$ \\
\hline
\end{tabular}
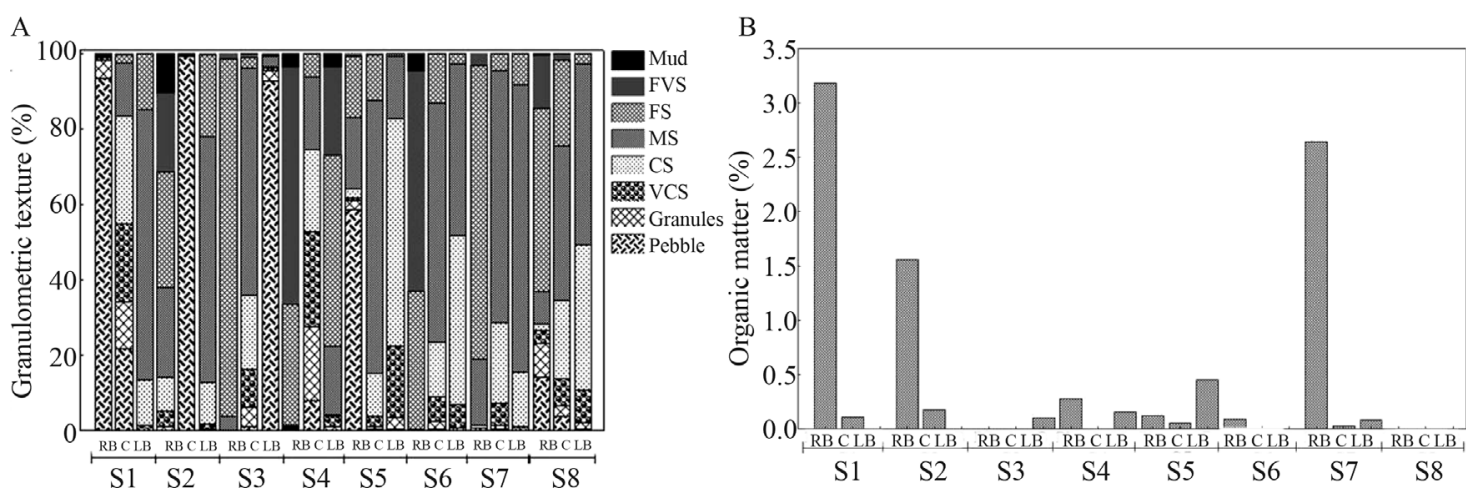

Figure 2 - Organic matter $(\mathrm{A})$ and granulometric texture $(\mathrm{B})$ of sediment from the Paraná River $(\mathrm{RB}=$ bank right region; $\mathrm{C}=$ center region; $\mathrm{LB}=$ bank left region; $\mathrm{VFS}=$ very fine sand; $\mathrm{FS}=$ fine sand; $\mathrm{MS}=$ medium sand; $\mathrm{CS}=$ coarse sand; $\mathrm{VCS}=$ very coarse sand).

Table 2 - Results of two-way (stations and sites) analysis of variance (ANOVA) for the biological variables.

\begin{tabular}{|c|c|c|c|c|c|c|c|c|c|c|c|c|}
\hline \multirow[t]{2}{*}{ Factor } & \multicolumn{3}{|c|}{ Abundance (ind.m ${ }^{-2}$ ) } & \multicolumn{3}{|c|}{$\begin{array}{c}\text { Richness } \\
\text { (number of taxa) }\end{array}$} & \multicolumn{3}{|c|}{ Diversity (H') } & \multicolumn{3}{|c|}{ Evenness (J') } \\
\hline & df & $\mathbf{F}$ & $\mathbf{p}$ & df & $\mathbf{F}$ & $\mathbf{p}$ & df & $\mathbf{F}$ & $\mathbf{p}$ & df & $\mathbf{F}$ & $\mathbf{p}$ \\
\hline Station & 7 & 2.10 & $0.05 *$ & 7 & 11.80 & $0.00 *$ & 7 & 5.07 & $0.00 *$ & 2 & 3.87 & $0.04 *$ \\
\hline Site & 2 & 0.08 & 0.93 & 2 & 3.97 & 0.06 & 2 & 1.77 & 0.18 & 0 & - & - \\
\hline Station x Sites & 14 & 2.20 & $0.02 *$ & 14 & 10.42 & $0.00 *$ & 14 & 4.70 & $0.00 *$ & 9 & 3.15 & $0.02 *$ \\
\hline
\end{tabular}

*Significant results, with $\mathrm{p}<0.05$. 

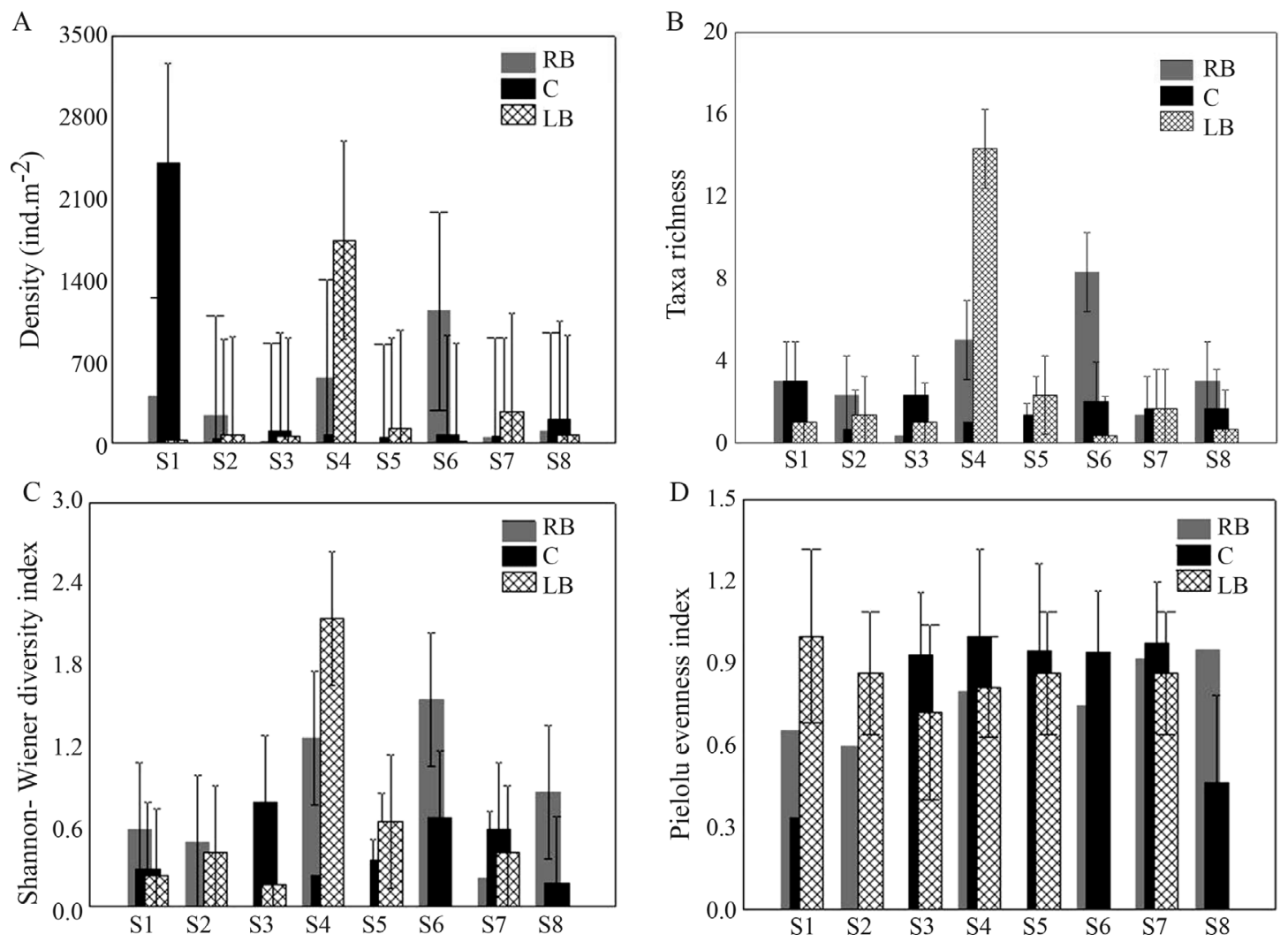

Figure 3 - Abundance (A); richness (B); diversity (C) and evenness (D) (mean \pm SE) of Chironomidae assemblage at the eight sampling sites of Paraná River $(\mathrm{S})(\mathrm{RB}=$ right bank region; $\mathrm{C}=$ center region; $\mathrm{LB}=$ left bank region).

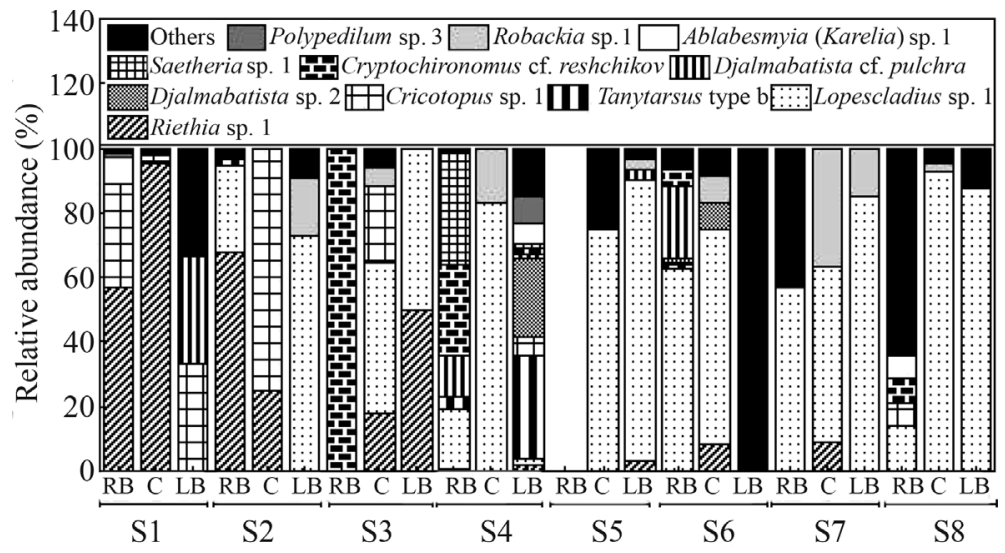

Figure 4 - Relative abundance of Chironomidae larvae taxa at the eight sampling sites $(\mathrm{S})$ of Paraná River $(\mathrm{RB}=$ right bank region; $\mathrm{C}=$ center region; $\mathrm{LB}=$ left bank region).

coarse fractions in sediment, presence of $L$. fortunei and high densities of Riethia sp.1, Nilothauma sp.1, Caladomyia type B, Saetheria sp. 2, Thienemmaniella sp.3. A second group was comprised of highest densities of Nilothauma sp. 6, Harnischia complex sp. 3c; Saetheria sp. 1, Cryptochironomus cf. reshchikov, Djalmabatista cf. pulchra and great proportions of fine fractions in the sediment (fine sand and mud).

\section{Discussion}

Damming of river modifies floods intensity, duration and periods of downstream stretch, and reduces nutrients loads to floodplain below of dam, as in the floodplain of upper Paraná River after Porto Primavera Reservoir. According Williams and Wolman (1984), dams built mainly for hydropower generation are effective sediment traps 
Pinha, GD. et al.

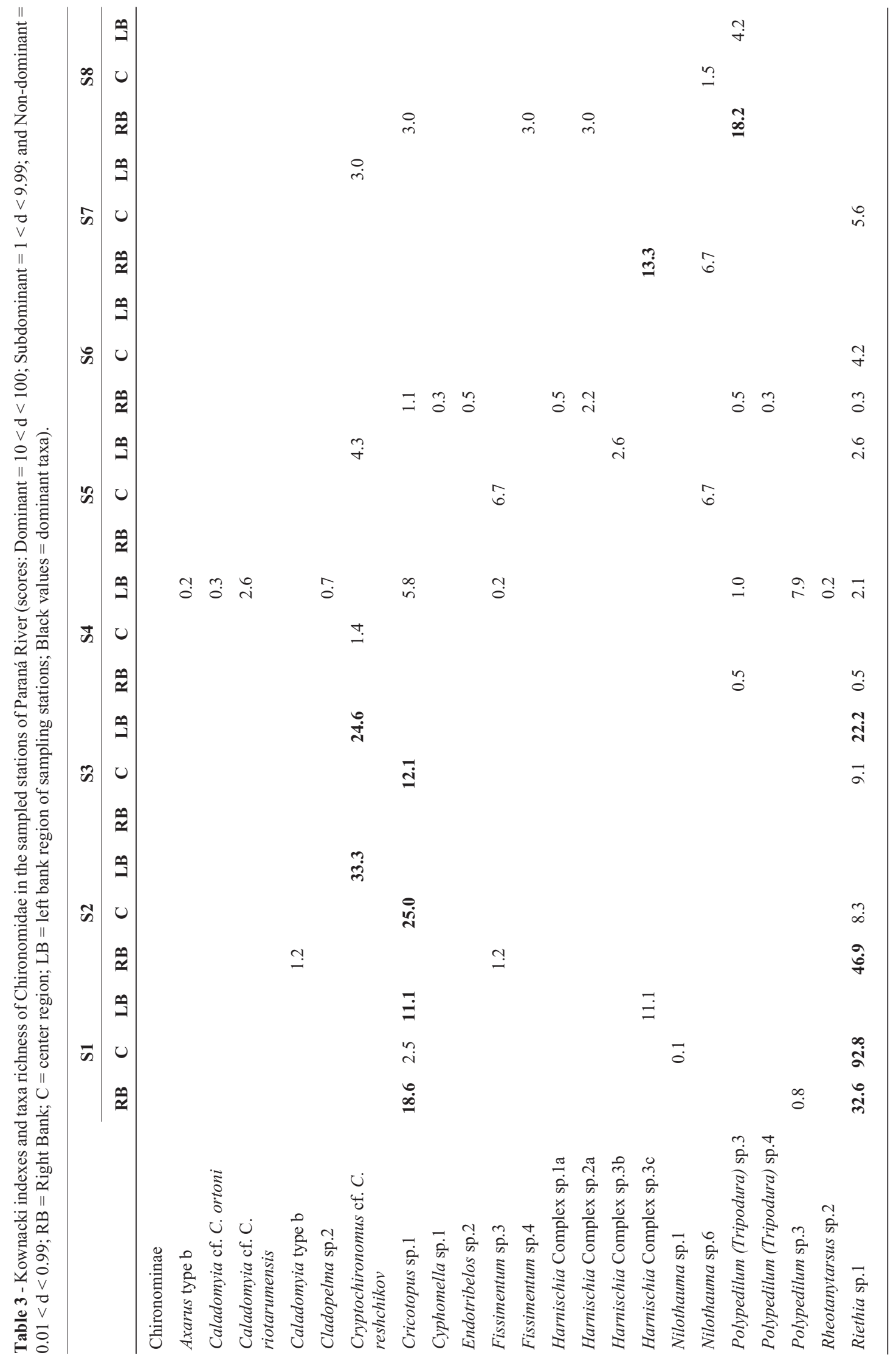


Longitudinal distribution of Chironomidae

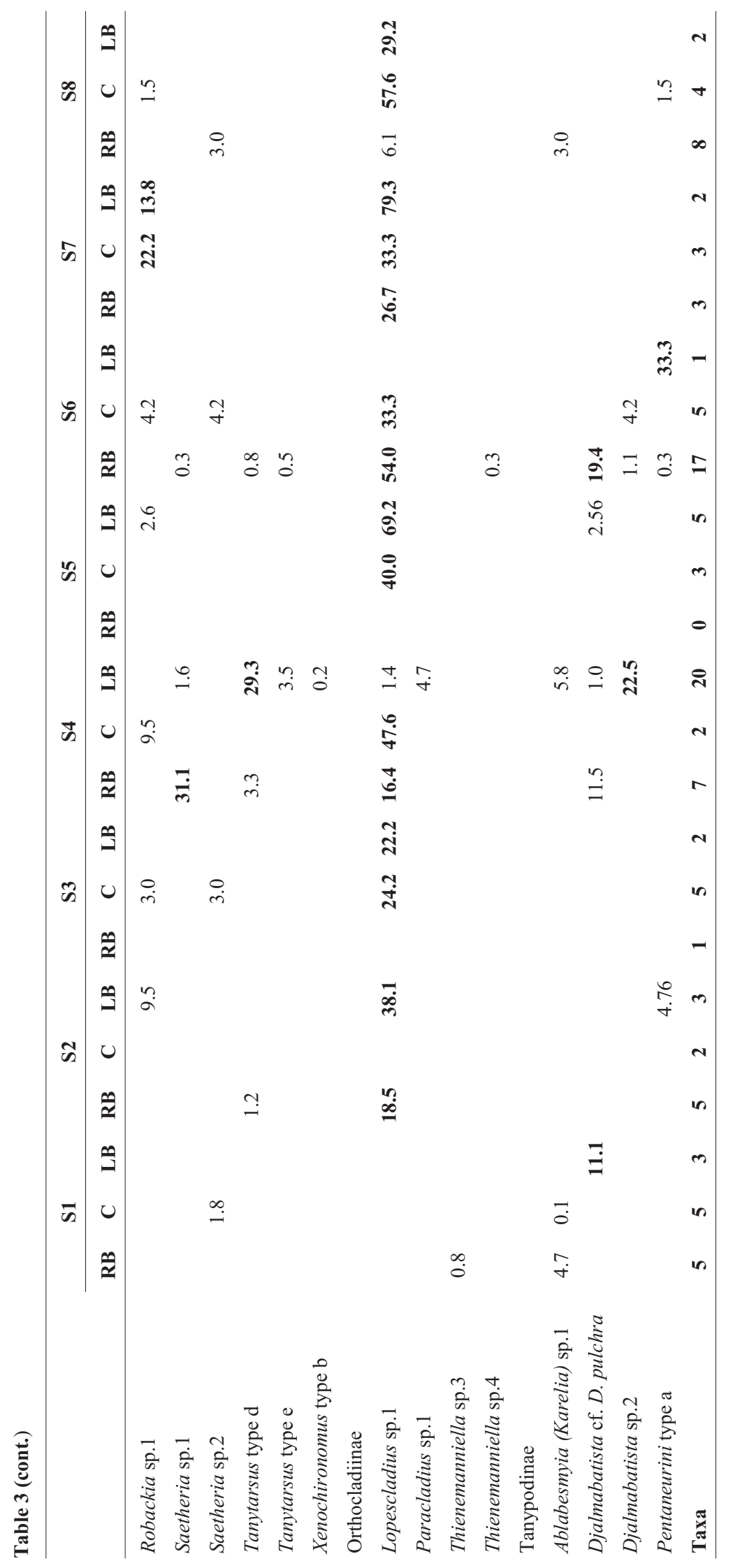




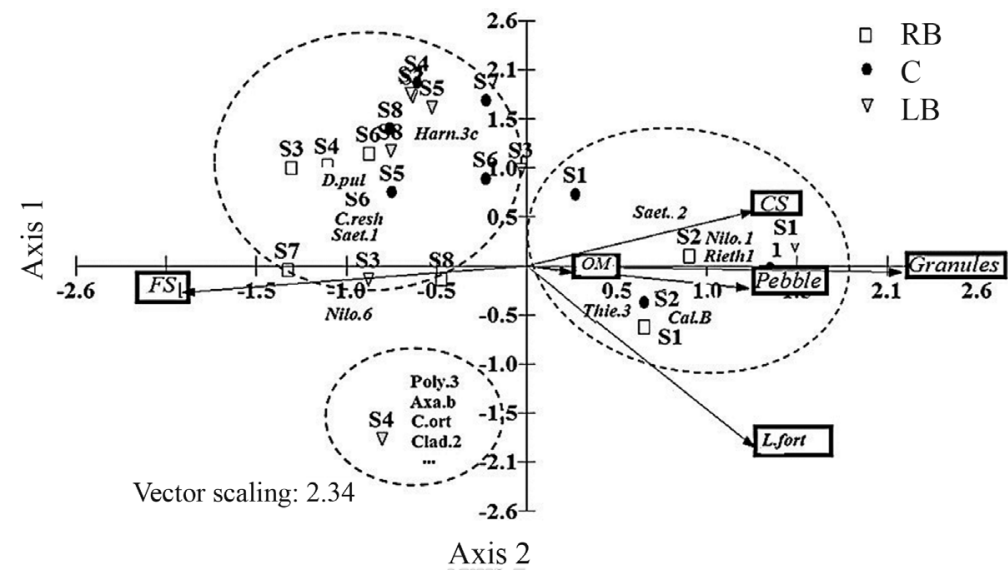

Figure 5 - Ordination diagram for the first two axes of Canonical Correspondence Analysis (CCA) with the scores ordination of 1 and 2 axes of sampled stations (S) and sites according to abiotic variables (FS= fine sand; $\mathrm{CS}=$ coarse sandy; $\mathrm{OM}=$ organic matter; L.for $=$ presence of Limnoperna fortunei) and Chironomidae (Nilo.1 = Nilothauma sp.1; Riet.1 = Riethia sp.1; Thie. $3=$ Thienemmaniella sp.3; Cal.b = Caladomyia type B; Saet.2= Saetheria sp. 2; Nilo.6= Nilothauma sp. 6; Harn.3.c=Harnischia Complex sp. 3c; Saet.1= Saetheria sp. 1; C.resh=Cryptochironomus cf. reshchikov; D.pul=Djalmabatista cf. pulchra; Poly.3 = Polypedilum sp.3; Axa.b = Axarus type b; C.ort = Caladomyia cf. C. ortoni; Clad.2 = Cladopelma sp.2).

as an incidental consequence of the dam's overall structure and operation and the reduction in sediment concentration on $5 \mathrm{~km}$ downstream from the dam is dramatic. This fact influences on benthic communities due to modifications caused by composition of sediment, especially near the dam. Construction of the Engineer Sergio Motta Dam changed hydrological and geomorphologic dynamics of Paraná River (Souza Filho et al., 2004). Dam changed flow, reduced supply of suspended load, modified bed forms and changed the pattern of bank erosion (Souza Filho et al., 2004).

These modifications caused very difficult to sampling, in stations S1 and S2, on rocky bed with few coarse sediment. Few of pebble and granules were collected in that areas, because there are a constant removal of fine sediment and no have replacement of load suspended sediment by upstream due to dam. The rocky bed river with few pebble and granules favored the establishment of invasive "golden mussel" Limnoperna fortunei in stations $\mathrm{S} 1$ and $\mathrm{S} 2$.

This species is recognized as invasive in floodplain of the Upper Paraná River since 2002 (Takeda et al., 2003). L. fortunei growths in consolidated substrates (Morton, 1973), as rocky bed of stations S1 and S2. Karatayev et al. (2010) introduces data about ability of this invasive species to shape aggregations (druses) and physically change substrates, providing shelter and food for other benthic organisms.

Golden mussel can be considered a "substrate", instead as another organism, affecting structure of Chironomidae assemblage. High density of golden mussel was not necessary to form a big druse because it could be aggregation of small individuals, while few big individuals together can form great druses.
Dominants larvae in stations $\mathrm{S} 1$ and $\mathrm{S} 2$ are better adapted to coarser substrate where can be found their food. Henrique-Oliveira et al. (2003) showed that Nilothauma and Thienemanniella eat detritus and periphyton. The larvae of Riethia are capable of ingesting detritus, large amounts of diatoms (Chessman, 1986). The rocky bed may have favored periphyton community and, golden mussel druse promoted much quantity of detritus for larvae providing by pseudo feces. In turn, Cricotopus larvae, dominant in stations $\mathrm{S} 1$ and $\mathrm{S} 2$, according to Berg (1995), is a common taxon in hard substrate.

Increasing the distance from the dam, contribution of finer sediment was due to tributaries transport into the Paraná River. According to Souza Filho et al. (2004), a major source of sediment suspended load of the Paraná River after the dam became from own bed and from banks erosion, especially in the period of higher water. The reduction of the suspended load of the Paraná River downstream of the reservoir, changed the color and transparency of the water (Souza Filho et al., 2004), resulting in lower values of turbidity, as observed in the present study.

The changes of substrate were one of decisive factor for the structure of Chironomidae assemblage. The availability of food, size and amount sediment particles are very important factors in distribution and occurrence of aquatic invertebrates assemblages (Williams and Mundie, 1978).

After 38 kilometers of dam (at station S4), bottom showed modifications on sediment composition from coarse or bed rocky to sandy. During 1993 to 1995, before the closing to former reservoir, Stevaux and Takeda (2002) observed that sediment was compound by medium, coarse and fine sand and found great abundance of 
Chironomidae larvae on left bank. In present study we found the most diversity and abundance of larvae in station S4 in left bank.

Subsequently the confluence of the tributaries (Paranapanema, Baía and Ivinhema rivers) the composition of the Chironomidae assemblage was altered, with changes of the dominant taxa which are typical of sandy lotic areas (sensu Sanseverino and Nessimian, 2001), like Lopesclaudius, Cryptochironomus, Harnischia complex morphotypes, Nilothauma, Polypedilum, Tanytarsus, Axarus. All taxa are common to the Paraná River (Higuti and Takeda, 2002; Rosin et al., 2010). Many of Chironomidae larvae are typically of depositional areas, with fine sediments, like the Lopesclaudius sp.1, the most common morphotype after the input of the tributaries.

The high flow of the Paraná River in center and banks sites characterizes this river as an environment with high instability. Blettler et al. (2012) showed that, in Paraná River (Argentina), there are active bed assemblage characterized by higher density values and $r$-strategist species and, other one inhabits of the banks, named as banked assemblage, with lower density and high diversity values, richness and evenness. Our data showed similar situation. Chironomidae genera, considered as r-strategist organisms, presented substantial modification in dominance between stations.

In conclusion, assemblage of Chironomidae larvae is one of the instruments of biota to be used as environmental sentinel of modifications caused by human as construction of dam. Dominance of Chironomidae genera change in consequence of modifications on water physical and chemical factors and, mainly on sediment texture of bed river.

\section{Acknowledgments}

The authors thank the financial support from the Curso de Pós-Graduação em Ecologia de Ambientes Aquáticos Continentais/Universidade Estadual de Maringá and CAPES/PROEX for the Zoobenthos Ecology subject and present research.

\section{References}

ABUJANRA, F., AGOSTINHO, AA. and HAHN, NS., 2009. Effects of the flood regime on the body condition of fish of different trophic guilds in the Upper Paraná River floodplain, Brazil. Brazilian Journal of Biology, vol. 69, no. 2 , p. $469-479$.

ARMITAGE, PD., CRANSTON, PS. and PINDER, LCV., 1995. The Chironomidae: biology and ecology of nonbiting midges. London: Chapman \& Hall.

BEHREND, RDL., FERNANDES, SEP., FUJITA, DS. and TAKEDA, AM., 2009. Eight years of monitoring aquatic Oligochaeta from the Baía and Ivinhema Rivers. Brazilian Journal of Biology, vol. 69, no. 2, p. 559-571.

BERG, MB., 1995. Larval food and feeding behavior. In ARMITAGE, P., PINDER, LC. and CRANSTON, PS. (Eds.). The Chironomidae, biology and ecology of non-biting midges. London: Chapman \& Hall. p. 136-168.

BLETTLER, MCM., AMSLER, ML., EZCURRA DE DRAGO, I., DRAGO, EC., PAIRA, AR. and ESPINOLA, LA.,
2012. Hydrodynamic and morphologic effects on the benthic invertebrate ecology along a meander bend of a large river (Paraguay River, Argentina-Paraguay). Ecological Engineering, vol. 44, p. 233-243.

CHESSMAN, BC., 1986. Dietary studies of aquatic insects from two Victorian rivers. Australian Journal of Marine and Freshwater Research, vol. 37, p. 129-146.

DARRIGRAN, G., MARTIN, SM., GULLO, B. and ARMENDARIZ, L., 1998. Macroinvertebrates associated with Limnoperna fortunei (Dunker 1857) in Rio de la Plata, Argentina. Hydrobiologia, vol. 367, no 1-3, p. 223-230.

DARRIGRAN, G. and DAMBORENEA, C., 2011. Ecosystem Engineering Impact of Limnoperna fortunei in South America. Zoological Science, vol. 28, p. 1-7.

DUDGEON, D., 1994. Research strategies for the conservation and management of tropical Asian streams and rivers. International Journal of Ecology \& Environmental Sciences, vol. 20, p. 255-285.

DYNESIUS, M. and NILSSON, C., 1994. Fragmentation and flow regulation of river systems in the northern third of the world. Science, vol. 266, no. 5186, p.753-762.

EPLER, JH., 2001. Identification manual for the larval Chironomidae (Diptera) of North and South Carolina. Crawfordwille: Special Publication.

FERRINGTON, L., 2008. Global diversity of non-biting midges (Chironomidae; Insecta-Diptera) in freshwater. Hydrobiologia, vol. 595, no. 1, p.447-455.

GUBIANI, ÉA., GOMES, LC., AGOSTINHO, AA. and OKADA, EK., 2007. Persistence of fish populations in the upper Paraná River: effects of water regulation by dams. Ecology of Freshwater Fish, vol. 16, p. 191-197.

GURTZ, ME. and WALLACE, BJ.,1984. Substrate-Mediated Response of Stream Invertebrates to Disturbance. Ecology, vol. 65, no 5, p. 1556-1569.

HENRIQUE-OLIVEIRA, AL., DORVILLÉ, LFM. and NESSIMIAN, JL., 2003. Distribution of Chironomidae larvae fauna (Insecta: Diptera) on different substrates in a stream at Floresta da Tijuca, RJ, Brazil. Acta Limnologica Brasiliensia, vol. 15, p. 69-84.

HIGUTI, J. and TAKEDA, AM., 2002. Spatial and temporal variation in of Chironomid larval (Diptera) in two lakes and two tributaries of the Upper Paraná River floodplain. Brazilian Journal of Biology, vol. 62, p. 807-818.

KARATAYEV, AY., BURLAKOVA, LE., KARATAYEV, VA. and BOLTOVSKOY, D., 2010. Limnoperna fortunei vs. Dreissena polymorpha: population densities and benthic community impacts of two invasive freshwater bivalves. Journal of Shellfish Research, vol. 29, no. 4, p. $975-984$.

KOWNACKI, A., 1971. Taxocens of Chironomidae in Polish high trataments. Acta Hydrobiologica, vol. 13, no. 4, p. 439-464.

MAASRI, A., FAYOLLE, S., GANDOUING, E., GARNIERG, R. and FRANQUET, E., 2008. Epilithic chironomid larvae and water enrichment: is larval distribution explained by epilithon quantity or quality? North American Benthologic Society, vol. 27, no. 1, p. 38-51.

MATSUMURA-TUNDISI, T., 1999. Diversidade de zooplâncton em represas do Brasil. In HENRY, R. (Eds.). Ecologia de reservatórios: estrutura, função e aspectos sociais. Botucatu: FUNDBIO/FAPESP. p. 39-54.

MORTON, B., 1973. Some aspects of the biology and functional morphology of the organs, of feeding and digestion of Limnoperna fortunei (Dunker) (Bivalvia: Mytilacea). Malacologia, vol. 12, number 2, p. 265-281. 
MOULTON, TP., 1998. Saúde e integridade do ecossistema e o papel dos insetos aquáticos. In NESSIMIAN, JL. and CARVALHO, A. L. (Eds). Ecologia de Insetos Aquáticos. Rio de Janeiro: Editora UFRJ. p. 281-298. Serie Oecologia Brasiliensis, vol. 5.

MURAKAMI, EA., BICUDO, DC. and RODRIGUES, L., 2009. Periphytic algae of the Garças Lake, Upper Paraná River floodplain: comparing the years 1994 and 2004. Brazilian Journal of Biology, vol. 69, no. 2, p. 459-468.

ORFEO, O. and STEVAUX, JC., 2002. Hydraulic and morphological characteristics of middle and upper reaches of the Paraná River (Argentina and Brazil). Geomorphology, vol. 44, p. 309-322.

PETTS, GE., 1989. Perspectives for ecological management of regulated rivers. In GORE, JA. and PETTS, GE. (Eds.). Alternatives in regulated river management. Boca Raton, USA: CRC Press. p. 3-24.

PIELOU, EC., 1966. The measurement of diversity in different types of biological collections. Journal of Theoretical Biology, vol.13, p.131- 144.

PIELOU, EC., 1975. Ecological diversity. New York: John Wiley. p. 165.

RODRIGUES, LC., TRAIN, S., BOVO-SCOMPARIN, VM., JATI, S., BORSALLI, CCJ. and MARENGONI, E., 2009. Interannual variability of phytoplankton in the main rivers of the Upper Paraná River floodplain, Brazil: influence of upstream reservoirs. Brazilian Journal of Biology, vol. 69 , no. 2 , p. 501-516.

ROSIN, GC., OLIVEIRA-MANGAROTTI, DP., TAKEDA, AM. and BUTAKKA, CMM., 2009. Consequences of a dam construction upstream from the Upper Paraná River floodplain (Brazil): temporal analysis of the Chironomidae community over an eight-year period. Brazilian Journal of Biology, vol. 69, p.591-608.

ROSIN, GC., OLIVEIRA-MANGAROTTI, DP. and TAKEDA, AM., 2010. Chironomidae (Diptera) community structure in two subsystems with different states of conservation in a floodplain of southern Brazil. Acta Limnologica Brasiliensia, vol. 22, p.276-286.
SANSEVERINO, AM. and NESSIMIAN, JL., 2001. Hábitats de larvas de Chironomidae (Insecta, Diptera) em riachos de Mata Atlântica no Estado do Rio de Janeiro. Acta Limnologica Brasiliensia, vol. 13, no. 1, p. 29-38.

SOUZA FILHO, EE. and STEVAUX, JC., 2004. Geology and geomorphology of the Baía-Curutuba-Ivinheima river complex. In THOMAZ, SM., AGOSTINHO, AA. and HAHN, NS. (Eds.). The Upper Paraná River and its floodplain: physical aspects, ecology and conservation. Leiden: Backhuys Publishers. p. 1-29.

SOUZA FILHO, EE., ROCHA, PC., COMUNELLO, E. and STEVAUX, JC., 2004. Effects of the Porto Primavera dam on physical environment of the downstream floodplain. In THOMAZ, SM., AGOSTINHO, AA. and HAHN, NS. (Eds.). The Upper Paraná River and its floodplain: physical aspects, ecology and conservation. Leiden: Backhuys Publishers.

STEVAUX, JC. and TAKEDA, AM., 2002. Geomorphological processes related to density and variety of zoobenthic community of the upper Paraná River. Zeitschrift Fuer Geomorphologie, vol. 129, p. 143-158.

SYROVÁTKA, V., SCHENKOVÁ, J. and BRABEC, K., 2009. The distribution of chironomid larvae and oligochaetes within a stony-bottomed river stretch: the role of substrate and hydraulic characteristics. Fundamental Applied Limnology, vol. 174, no. 1, p. 43-62.

TAKEDA, AM., MANSUR, MCD., FUJITA, DS and BIBIAN, JPR., 2003. Ocorrência da espécie invasora de mexilhão dourado, Limnoperna fortunei (Dunker, 1857), em dois pequenos reservatórios próximos a Curitiba, PR. Acta Biologica Leopoldensia, vol. 25, no.2, p.251-254.

TRIVINHO-STRIXINO, S., 2011. Larvas de Chironomidae. Guia de Identificação. São Carlos: Depto Hidrobiologia/Lab. Entomologia Aquática/UFSCar.

WENTWORTH, CK., 1922. A scale of grade and class trems for clastic sediments. Journal of Geology, vol. 30, p. 377-392.

WILLIAMS, GP., and WOLMAN, GP. 1984. Downstream Effects of Dams on Alluvial Rivers. Washington: USGPO. p. 88. Geological Survey professional paper. 